\title{
НОМИНАЦИЈА УЧЕСНИКА У СВАДБЕНИМ ОБИЧАЈИМА КОД СРБА У СРБИЈИ И РУМУНИЈИ
}

\begin{abstract}
Номинација учесника у свадбеним обичајима сведочанство је о тим обичајима. Стога ће она у различитим крајевима бити различита. У овоме раду анализирани су називи учесника у тим обичајима код Срба у Србији и код Срба у Румунији са намером да се покаже да су ти називи сведочанство о томе шта је у свадбеним обичајима заједничко, а шта резултат језичке и културне интерфенције. Грађа за анализу преузета је из публикованих радова: речника, монографија о појединим говорима или из радова у којима се обрађују свадбени обичаји.
\end{abstract}

Кључне речи: учесници, номинација, свадба, сват, кум, стари сват, девер.

1. О томе да нестају стари „добри“ обичаји често говоримо. И поред носталгије за тим временима, мора се признати да је то неминовност која долази са променама у начину живота. У оне обичаје који, истина у измењеном облику, ипак опстају спадају обичаји животног циклуса, а међу њима и свадбени обичаји.

Отуда се јавља потреба за бележењем тих обичаја пре него што и они који их још памте нестану или их забораве. То значи да се заправо неминовно покушава реконструкција заборављених обичаја. За језичаре је посебно важно бележење лексике којом се именују појаве, догађаји, предмети и особе у вези са одређеним обичајем или обредом.

Предмет овога рада јесу номинационе јединице за учеснике у свадбеним обичајима. Такве лексичке јединице су доста бројне у српском језику. У тај инвентар су укључене особе са улогом у предсвадбеним обичајима, у току свадбе и непосредно након свадбе

Многе лексичке јединице тога инвентара су нестале зато што су нестале функције које су ти учесници имали јер су главни део организације свадбене церемоније преузели ресторани и отпочели да диктирају начин и ток церемоније.

\footnotetext{
${ }^{1}$ jordana.markovic@filfak.ni.ac.rs

${ }^{2}$ Овај прилог резултат је рада на пројекту 178020 - Дијалектолошка истраживања српског језичког простора, који у целини финансира Министарство просвете, науке и технолошког развоја Републике Србије.
} 
Грађа за ову анализу преузета је из публикованих радова са том тематиком или из дијалектских речника. Ти подаци тичу се учесника у свадбеним обичајима код Срба у Србији, али и код Срба из Румуније, код Карашевака, пре свега, али и код Свиничана и становника села Радимна. До таквих података са простора Румуније дошла сам из радова Михаја Радана, Миљане Радмиле Ускату и из докторске дисертације К. Д. Владимировне, мада су у тој дисертацији инкорпорирани и подаци поменутих колега, за Карашево. За Свиницу и Радимну податаке сам преузела из радова Милета Томића, иако се мора имати у виду да његов циљ није био да се баш овом лексиком бави, па се може претпоставити да су бројни подаци овога типа изостали. Мањи део ове лексичке грађе потиче из рада Василке Алексове, која се бавила компаративном анализом свадбене терминологије у бугарском и румунском језику (Алексова, 2013), па су се спорадично нашли и термини код Срба у Румунији. Заправо, мора се имати у виду да су често ови подаци селективни, будући да се нико од поменутих аутора није првенствено бавио овом лексиком - номиновањем учесника скупа ${ }^{3}$, а временска (и просторна) дистанца учинила је да се у неке податке сумња, а неки се просто нису појавили, а истраживачи за њих нису знали да би за њима трагали.

Ова и свака друга слична анализа валидна је у мери у којој је валидна грађа на основу које је сачињена, а о томе да она не одговара у потпуности стварном стању сведоче бројни детаљи.

Циљ овог осврта јесте да се кроз анализу овога инвентара покаже шта је истоветно у обичајима Срба који живе у двема државама, а шта је резултат индивидуалног културолошког развоја или утицаја окружења.

2. Преглед грађе биће дат по семантичким пољима. Анализирани материјал разврстан је на 11 семантичких целина:

- учесник свадбе уопште,

- главни учесници свадбе (младенци),

- сведоци на венчању,

- учесници са специјалном улогом,

- дете које се даје невести,

- незвани сватови,

- гости из младиног дома,

- рођаци као учесници свадбе,

- именивање особа према новонасталим односима,

- музичари,

- кулинари.

\footnotetext{
${ }_{3}^{3}$ Један део рада М. Радана посвећен је учесницима у свадбеним обичајима и ритуалима (2006: 66).
} 
У оквиру сваког од тих семантичких поља биће дат паралелни преглед посматраних лексема код Срба у Србији и код Срба у Румунији, како би се уочило шта је исто или слично, а шта другачије. Будући да су ове номинационе јединице већ биле предмет мог рада Учесници у сбадбеним обичајима, који је био прочитан на научном скупу Обичаји у култури Срба и Бугара одржаном октобра месеца 2019. на Филозофском факултету у Нишу и у овом тренутку је у процесу припреме за штампу, овде су такве лексичке јединице са простора Србије најчешће само побројане, а често не представљају ни целокупну грађу, већ само ону која се може компарирати са грађом са простора Румуније. То значи да су изостале неке језичке јединице које нису имале паралелу.

2.1. У ч е с н и к с в а д б е у о п ш т е. У Србији се са значењем 'учесник у свадбеној поворци', 'онај ко много воли да се појављује на свадбама', 'учесник свадбе с младожењине стране', 'гост на свадби', 'чест гост на свадбама', 'званица на свадби' и сл. јављају бројне лексеме: свадбароши, свадбари, сватови, гости, званице, узов и сл.

Код Срба у Карашеву налазимо: свадбаши, али и: сватови. У тексту из Свинице, поред свадбаш, јавља се и свативе 4 , уколико није у питању штампарска грешка, али и гоћu' $e^{5}$, где је опет вероватно у питању штампарска грешка. У Радимни је свадбаш (Томић, 1989: 134), али у текстовима и сватови - момкови сватови и девојкини сватови (Томић, 1987: 453, 454).

Међу лексемама сватови и свадбари може постојати (и обично и постоји) семантичка разлика, па је сват учесник сватова, а свадбар/ свадбарош/ свадбаш учесник свадбе. У РМС стоји информација да је cват 'учесник у свадбеној поворци, гост, званица на свадби', али и 'члан зетовљеве породице', а свадбар је 'сват'. У РС је свадбар 'учесник у свадби са девојачке стране; сват', а сват је 'учесник у свадби с младожењине стране; уопште гост; званица на свадби и у свадбеној поворци’. Јасно је из ових дефиниција да је семантичка диференцијација само могућност.

2.2. Г л а в н и у ч е с н и ц и с в а д б е (м л а д е н ц и). Главним учесницима свадбе морају се сматрати младенци будући да без њих нема свадбе.

2.2.1. Млада и младожења номинују се лексемом младенцุи.

2.2.2. У значењу 'онај који се жени, који ступа у брак' на простору Србије јавља се: младожења, младенеи, женик, војно, ђувеглија, ђувегија. Код карашевских Срба и у Радимни имамо младожења, а у Свиници у значењу 'младожења' стоји младоженија, док се код одреднице младожења упућује на

\footnotetext{
${ }^{4}$ „И су рано били код нас свативе. Су лепо фруштукали, су пили и посе су ошли“ (Томић, 1984: 254).

5 „По селу и сабирали из музиком гоћ'ше, от краја на крај, сви“ (Томић, 1984: 254).
} 
младоженија, а тамо уз младожена постоји напомена вар. (Томић, 1984: 172).

У РМС младожења је 'мушкарац у време своје женидбе, мушкарац који ступа у брак, женик', а код одреднице женик стоји напомена да је лексема арх., са значењем 'онај који ступа у брак, младожења'.

По РМС, Ђувегија је 'заручник, вереник; младожења'. Лексема војно доводи се у везу са 'младим јунаком', јер, по тврђењу Алексове, „походът за невестата е като средновековна военна експедиция“‘ (2013: 170).

2.2.3. За женску особу која ступа у брак у Србији налазимо: младаневеста, младеневеста, младевеста, млада, младица, млатка, невеста ${ }^{6}$, невесте, невестенце, невестица, невестиче, неја, нејћа.

Код Срба у Румунији се бележи: млада, невеста ${ }^{7}$ и говија (Томић, 1984: 131).

Лексеме млада и невеста забележене су и у РМС. У овом речнику нема лексеме младаневеста, а нема је ни у РСЈ.

У Карашеву се јавља: дефка, дежка в. деука, девка (Владимировна, 2019: 123). У Свиници у значењу 'млада' постоји деука и девка (Томић, 1984: 25).

У једном наративу из Карашева стоји: „Дететова фамила: мама, свекрва, свекар, и младожењина главна фамила“, као и: „Свадбу, стари сват је од дитета, озли дитета, дете мете, дитетов је кум и дитетов је стари сват“ (Владимировна, 2019: 102), одакле видимо да се младожења номинује лексемом дите.

Појава лексеме говија у Свиници може се довести у везу са глаголом говети у значењу 'пријати, допадати се'8. Алексова доноси лексему góvie (са фонетским варијантама), за коју каже да је спорадично забележена у Банату, али да се јавља и у 17. веку у текстовима из области Молдаве са значењем 'девојка, девица', па се одатле, како претпоставља В. Скурту, развило значење 'младоженка' (Алексова 2013: 181).

Код Срба у Румунији нема лексема: побегуља ${ }^{9}$, побегуљћа, пристањишка ${ }^{10}$, крадена девојка ${ }^{11}$, какве налазимо у Србији. Према тврдњи

\footnotetext{
${ }^{6}$ Трагајући за етимологијом ове лексеме, Алексова као најприхватљивије прихвата тумачење по којем је невеста заправо „неизвестна“, „непозната“, „чужда“, „нечиста“ (2013: 185), при чему се семантика доводи у везу са прасловенским кореном *ved- са значењем 'знати'. Алексова тврди да се ова лексема јавља у свим словенским језицима (2013: 185), али она представља најстарији слој словенских позајмљеница у румунском језику (2013: 186).

${ }^{7}$ Радан тврди да је термин невеста ређе у употреби (Радан, 2006: 67).

${ }^{8}$ О овом глаголу у вези са понашањем младе у време свадбе говори и Алексова $(2013: 169,170)$.

${ }^{9}$ Ова лексема је регистрована и у РСЈ и има два значења: 1. 'женска особа која од .мужа побегне у род'; 2. 'девојка која од родитеља побегне момку ради удаје'.

10 'Девојка која се пристала, која је побегла за момка' (Богдановић, 2016: 167). Овакав начин склапања брака познат је и у Бугарској, о чему сведоче термини пристанка, пристанала, пристануша (Легурска и др., 2012: 59).

${ }^{11}$ Овај вид склапања брака (против воље младе и њених родитеља, тако што је одвођена на силу, украдена) познат је и у Бугарској (Легурска и др., 2012: 59).
} 
колеге Михаја Радана обичај јесте познат, али редак, што се уклапа и у информације из рада Василке Алексове, која бележи велики број таквих лексема у бугарском ${ }^{12}$, а налази и један такав термин у румунском fugita (Алексова, 2013: 26).

2.3. С в едоци на венча њу и при падници њ ихов е пород и ц е. Овај део се односи на именовање првог и другог сведока на венчању.

2.3.1.1. Први сведок је кум, а његова жена кума или кумищза.

Тако је и код Срба у Румунији: кум, кума и кумица (Владимировна, 2019: 104; Томић, 1989: 65; Томић, 1984: 163).

У Радимни се јавља и кујка и кумача са значењем 'пријатељица, другарица, посестрима која се стиче кумачењем’ (Томић, 1989: 65), што није у вези са овом улогом.

2.3.1.2. Код Радана налазимо и термин фељин и, како се тамо каже: „Тако зове кум, односно кума, оне које је крстио и венчао, кумче“. По њему, „реч је стара позајмљеница из дакорумунског језика“ (Радан, 2006: 71).

2.3.2. Други сведок је: стари сват, старојко, старејко, старојка, старојћа; старосватица, старејковица; или: побратим; посестрима, побратимка ${ }^{13}$.

Код Срба у Румунији јавља се: стари сват, старисват, старисфат (Владимировна, 2019: 104), тј. стари сват, старојко, односно старасваја, стара сваја ${ }^{14}$.

У Србији је стари сват најчешће младожењин ујак. У наративима из Карашева стоји да је то младожењин брат, при чему се информатор позива на песму „узми ме за кума или старог свата, или за девера ако немаш брата“, мада тумачење ове песме не би требало да буде такво, јер се ово „ако немаш брата“" односи само на функцију девера.

2.4. О с тали уч е сни ци с а с п еци јално м улого м. Бројни су учесници свадбе који су имали посебно задужење: да носе барјак, чувају младу, забављају госте, нуде пићем, најављују госте итд., па се јавља: абериија, анђија, барјактар, барјатар, војвода, гласници, глумаи, деверуша, добарјактар, китарка, кондириија, кравајћа, льжљља, муштулугција, муштулција, наводација, оглачија, огледник, позивар, проводачија, просиои, утичњак, чауш, чајо, шалиција и др.

\footnotetext{
${ }_{12}$ То су: бегалка, беганка, бегулка, бежанка, бегалииа, бегана невеста, съмудойде и др. (Алексова, 2013: 26).

${ }^{13}$ Термин побратим и посестрима као синоним за старисват забележен је и у другим словенским говорима (Алексова, 2013: 224, 225).

${ }^{14}$ У РМС сваја је хип. од сваст, свастика.
} 
Овако бројни лексички инвентар у принципу изостаје код Срба у Румунији и то може бити веома значајан податак у вези са етнолошким, али и другим проучавањима.

2.4.1. Особа која проси девојку (сам момак или неко од његове родбине) номинује се као просаи, просиои, тькмеиија (Богдановић 2016: 199). Радан бележи просници 'просиоци у свадбеном обичају' (Радан, 2006: 71), а такву одредницу (просник) у значењу 'просилац' налазимо и у Говору Свиничана (Томић, 1984: 204).

2.4.2. Владимировна помиње стек $^{15}$ и објашњава да заставу носи чауш/ cmегар - рођак са младожењине стране (Владимировна, 2019: 100, 127). У Србији је таква особа најчешће ниминована као барјактар.

РМС има стегоноша 'онај који носи стег, барјактар', али нема стегар, а тако је и у РСЈ.

Код Ускату налазимо: „До друге половине прошлога века, чауш (стегоноша) $^{16}$ је обично била старија особа која је познавала све сватове и имала посебно задужење да на свадби гласно приказује све примљене дарове, а касније је за чауша биран дечак чије је главна улога била да предводи свадбу носећи стегк и повицима оглашава свадбену поворку“ (Ускату, 2017: 511).

2.4.3. Код карашевских Срба посебну улогу имају мошули. По Ускату: „Испред младожењине куће млади брачни пар дочекују мошуље (<рум. моș „старац“) то су биле маскиране особе (најчешће прерушени у младу и младожењу), обучене у старим, похабаним хаљинама, који су збијали разне шале ради разоноде и стварања што веселије атмосфере међу сватовима“ (Ускату, 2017: 512). Таква лексема није регистрована у Радимни и Свиници.

2.4.4. Значајна улога припада особи задуженој да шалама и досеткама развесељава госте и скреће пажњу на себе како би младенце заштитила од негативних утицаја. У Србији номинација такве особе је различита: чауші ${ }^{17}$,

15 Владимировна износи тврдњу Б. Сикимић да је стег аутохтони румунски термин (Владимировна, 2019: 348), позивајући се на дистрибуцију лексеме, иако је заправо лексема могла бити прасловенског порекла. У статистичкој обради података Владимировна ову лексему сврстава у лексеме најасне етимологије (2019: 149). Алексова истиче да се у дакороманском ареалу као термин за свадбену заставу најчешће јавља назив steag и да је ова лексема у румунским речницима обично идентификована као књижевнословенска позајмљеница (2013: 369, 370). У РСЈ уз ову лексему стоји арх. и песн.

${ }^{16}$ Радан у вези са овим тврди: „Интересантано је напоменути да Румуни (у српском Банату) за чауша користе словенску позајмљеницу - stăghiş/из рум. stéag 'барјак, застава' [...]. Практично, ч’áyz је главни актер, без његовог присуства не одвија се ниједан важнији свадбени обред“ (Радан, 2006: 68).

${ }^{17}$ По информацијама из Шкаљићевог речника, чауи има доста значења, а као 5. наведено је: 'вођа сватова, који се брине о реду у сватовима' и као 6. 'шаљивчина који развесељава сватове и госте на свадби' (1966: 165). 
глумац, льжљља, шалција. Таква улога неког од сватова морала је постојати и код Срба у Румунији (код Карашевака то је чауш, према подацима које налазимо код Ускату, 2017). Код Алексове налазимо да је термин mincinosul, чије значење је у вези са лаж (Алексова, 2013: 249), познат у једном делу Румуније (у неким селима у Трансилванији). Алексова бележи и термин чауш (у румунском сеauş /ceiuş), тврдећи да се јавља код Крашована у Банату и позивајући се на податке М. Радана ${ }^{18}$ (Алексова, 2013: 239).

2.4.5. Битну улогу у свадбеној церемонији има девер. У наративима из Карашева налазимо да су два девера са заставом чувала младу. Номиновани си и као деверље. То су невестина браћа или њени други рођаци мушког пола. Према информацији колеге Михаја Радана, код Карашевака један од девера је био са младожењинњ, а други са младине стране. Они су били њени помоћници и заштитници (Владимировна, 2019: 103).

Лексема девер у РС дефинисана је као 1. 'мужевљев брат или рођак из истог поколења'; 2. етн. 'пратилац младе на венчању (обично младожењин брат или рођак)'.

2.4.6. Јавља се и деверуша и она је младина „другарица, шта је ишла, деверуша, шта је била поред девера“ (Томић, 1987: 454). Слично је ова лексема дефинисана и у РСJ - то је 'девојка која прати младу на венчање' (РСЈ под деверуша).

2.4.7. 'Мушки сватови који из младине породице долазе и доносе јој преосталу гардеробу’ појеративно су називани дрзарима (дрза „стара, похабана хаљина, крпа“), по бележењу М. Р. Ускату (2017: 512). Овакав термин забележен је и у бугарском ${ }^{19}$.

О овом термину Радан даје више података. Он каже да су то „младини родитељи и родбина који у понедељак увече доносе у диса́зи (бисаге) или у тра́њеслу (већа вунена или пртена торба), у младожењину кућу, дарове за кума, куму, старог свата, ба́бу («жена /ређе девојка/, блиска рођака, која при крштењу носи новорођенче до цркве, где га даје куму, ако је мушко, односно куми, ако је женско») и младожењине укућане“" и додаје да је етимологија нејасна. Помишља на могућност да је термин настао од лексеме дрза у значењу које наводи и Ускату, и позивајући се на румунски. Он помишља и на везу са кореном дрз- у значењу 'дрскост, смелост', али и на везу са значењем 'онај који јемчи за нешто, јемац' (Радан, 2006: 69, 70) 20.

\footnotetext{
${ }^{18}$ Потврду налазимо и код Владимировне (2019: 100, 127) и Ускату (2017: 511).

${ }^{19}$ Термини дързер, дързерин за мушку и дързарка за женску особу регистровани су и у раду Неде Павлове о свадбеној терминологији, с напоменом да потиче из Баната (Легурска и др., 2012: 68).

20 Будући да је ареал употребе ове лексеме шири, Радан помишља да „ова лексема највероватније потиче из балканског лексичког супстрата“ (Радан, 2006: 70).
} 
2.4.8. Особа чији је задатак био да на дан венчања чува младожењиног коња, а самим тим и младожењу од врачара и да увече пред сватовима покаже младине поклоне за нову породицу, а његов задатак је био и да довезе девојачку спрему у неким крајевима, био је зет ${ }^{21}$ (Петровић-Савић, 2009: 112). Ове лексеме има у Карашеву, а и у Свиници и Радимни (Томић, 1984: 145; Томић, 1989: 46), али није забележена нека посебна улога ове особе у свадбеном обреду ${ }^{22}$.

2.4.9. У наративима о свадбеним обичајима Срба у Румунији помиње се и: господин, nопа ${ }^{23}$ (Томић, 1984: 254), који има улогу у венчању, али и у свадбеним обичајима. На српској страни томе се не придаје посебна пажња (можда више у вези са испитом пре свадбе). Такав податак је драгоцено сведочанство о односу према цркви.

Будући да обе лексеме налази и Радан, он даје занимљиво запажање: „Намеће се закључак да се лексема госпо́дин у КГ користи када се жели исказати извесно поштовање према свештенику, док се поп користи у фамилијарном смислу, без нијансе уважавања.“ (Радан, 2006: 71).

2.4.10. У наративу из Свинице јавља се и фотографист (Томић, 1984: 254). Да је на свадбама било фотографисања није спорно, али особа која се тим послом бавила није се сматрала учесником (или барем не обавезним учесником) свадбене церемоније.

2.4.11. У Радимни се јавља и говориија (на свадби) (Томић, 1989: 27). У РМС постоји говориија, са значењем 'говорљивац; говорник', али не помиње се улога такве особе у свадбеним обичајима. Међутим, овако номинована особа као учесник у свадбеним обичајима регистрована је у неким речницима са простора југоисточне Србије, мада улога такве особе није увек идентична, тј. није увек јасна ${ }^{24}$.

2.4.12. У Карашеву, према подацима до којих долази М. Радан налазимо и улогу хукача ${ }^{25}$. То би могла бити улога коју у Србији имају особе које најављују долазак сватова младожењиној кући и номинују се као:

\footnotetext{
${ }^{21}$ У неким местима зет је номинован поградно као пришупюак (Богдановић, 2016: 167).

${ }^{22}$ Ваља имати у виду и чињеницу да је као зет заправо номинован и младожења - он је зет члановима младине породице. Занимљива је тврдња Алексове по којој је ова лексема супротстављена лексеми невеста и налази се у односу познат : непознат, јер зет везује за индоевропски корен 'знати' (2013: 186).

${ }^{23}$ Владимировна има: “Господин чини предику / popa spune predica“" (2019: 108).

${ }^{24}$ У Речнику говора јужне Србије М. Златановића налази се одредница говориија са значењем 'просилац' и са позивом на народну песму из Прешева (2014: 109), а у Речнику лесковачког говора Б. Митровића говориија је 'проводаџија, наводаџија' (1984: 58).

${ }^{25}$ „Иду два-три хукача (подвикивача)“ (Радан, 2006: 68).
} 
муштулугција / муштулција ${ }^{26}$, утичњак ${ }^{27}$, гласниции ${ }^{28}$.

2.4.13. Насупрот сватовима са посебном улогом јавља се и 'сват без посебне улоге' номинован као пустосват, тј. пустосватица (РМС, под nустосват).

2.5. Д е т е к о е с е д а ј е н е в е с т и. Док је у Србији више различитих лексичких јединица за номинацију мушког детета које се даје невести при уласку у кућу: наконче, накоњче ${ }^{29}$, поздравче, понишало, понишалче, ускутче, код румунских Срба нема увек посебне лексеме којом се именује. У Радимни се јавља наконче (Томић, 1989: 80), али код Владимировне налазимо: „Поставе да седне и јој мету јено дете у крило, ман да је дете, мушкараи, да не је жена“" (2019: 106).

2.6. Н е з в а н и г о с т и. У доба кад свадба зађе у одмаклу фазу, у дворишту се појављују непозвани гости, обично младићи, и траже да им се изнесе јело и пиће, што неко у име домаћина и чини. Више различитих лексичких јединица сведочи о распрострањености овог обичаја код Срба: голосоврићи, стругар ${ }^{30}$, набигузица.

У грађи из Румуније нисам пронашла номинациону јединицу за учесника овог обичаја.

2.7. Г о с т и и 3 м л а д и н о г д о м а. Гости из младиног дома у току трајања свадбене церемоније одлазе у прву посету младожењиној кући. Овај обичај је у Србији распрострањен, а одвија се у различито време, па делом и стим у вези има и различитих назива за такве госте: повођани, пођани, пооцање, презовци, големи гости, првине, првенции.

И код Срба у Румунији постоји обичај у вези са првом посетом најближих младиних рођака младожењиној кући, али нисам уочила да су такви гости посебно именовани ${ }^{31}$.

\footnotetext{
26 'Сват који иде испред осталих сватова да најави њихов долазак' (Богдановић, 2016: 135).

27 'Онај (момак) који обавештава младожењину кућу да се свадбена поворка приближава' (БОГДАНОВИЋ 2016: 206).
}

28 'Два мушкарца који пре сватова одлазе у девојачку кућу и носе закланог брава и ракију' (БОГДАНОВИЋ 2016: 53).

${ }^{29}$ Овај се термин етимолошки доводи у везу са лексемом коњ, будући да се обично даје невести док је она на коњу. Истина, има и покушаја да се доведе у семантичку везу са лексемом 'почетак', чиме се везује за невестин почетак новог живота, тј. живота у новом дому (Алексова, 2013: 165).

${ }^{30}$ У Бугарској је забележен термин стугаре са значењем 'момчета, които се хранят на сватбата без да са поканени' (Легурска и др., 2012: 79).

${ }^{31}$ Бројне и занимљиве податке о овом обичају у Румунији (и код Румуна и код Срба) даје В. 
2.8. Р о ђа ц и к а о у ч е с н и ц и с в а д б е. Да и овај терминолошки слој треба уврстити овде, слажу се и други истраживачи. Владимировна, сврставајући ову лексику у „пресонажный код“, истичући: „В персонажный код свадьбы мы включаем все термины родства [...] как по внутриязыковым (теоретически все термины родства могли получать номинацию в качестве свадбеного чина), так и по внешнеязыковым (обязательное участие всех родствеников жениха и невесты в традиционной свадьбе, хотя бы в качестве рядовых гостей), причинам“ (2019: 128).

Овај део сведочи о томе да у свакој терминолошкој области има и лексичких јединица које припадају другој терминолошкој скупини, али јављају се и овде, као што има и лексема које припадају сфери опште употребе.

У свим радовима који се овом тематиком баве налазимо бројне термине из области терминологије сродства.

2.8.1. Заједничким именом 'лица са којима се неко налази у међусобном сродству и међу којима се не може склапати брак'32 номинују се као: родбина, род, родљак/родљака, роднина, рођа, рођак, фамилија, својина, својта, својак/својакиња, својштиња, ближањ, ближньи . $^{33}$ У Свиници је забележено родбина и род, као и фамелија. Владимировна има термин фамила (Владимировна, 2019: 113). Синтагма дитетова фамила код Карашевака значи 'породица младожење'. У Радимцима је фамилија (Томић, 1987: 453), али и родбина и ближюи (Томић 1987: 454).

2.8.2. Лаксемом родитељ номинује се 'мајка или отац'. Код Срба у Румунији је забележено родитељи и старешина (Владимировна, 2019: 130: Томић, 1984: 210, 220), у Радимни само родитељи (Томић, 1987: 454).

2.8.2.1. Мушки родитељ, који у неким крајевима има задатак да позива на свадбу и иде на прошевину, номинује се лексемама отац, бабаја, бабајћо, башта, тата, татко. У Карашеву постоји нена ${ }^{34}$ са значењем

Алексова (2013: 343). Она помиње и термин куилић'u, позивајући се на М. Радана, и доводећи овај термин у везу са румунским термином ospătul cel scurt sau al cînelui (2013:343). О томе говори и Владимировна (2019: 125). Она ову лексему сматра српскохрватским дијалектизмом (2019: 148).

${ }^{32}$ Овако је у Рађевини дефинисана ова лексема (Петровић-Савић, 2009: 143). У РСЈ родбина су 'сва лица са којима се неко налази у међусобном сродству, рођаци, сродници, својта'.

33 Занимљиво је да се јавља и лексичка јединица која је антоним овој. То је нерод 'особа с којом нисмо у сродству' (Богдановић, 2016: 144), а ту би се могла сврстати и лексема јабаниија/јабанцика, тј. јебаниија/јебаниика, са значењем 'туђинац, особа која није из рода, из фамилије' (Богдановић, 2016: 93), као и тућинаи 'несродник, стран човек' (Богдановић, 2016: 94).

${ }^{34}$ Тамо налазимо: „мама и нена младини“ (Владимировна, 2019: 103). Како примећује Радан, „Из старе словенске терминологије сродства сачуван је у КГ лексички архаизам за именовање 
‘отац', ‘свекар', 'таст' (Радан, 2006: 69). У значењу 'мушки родитељ' код Срба у Румунији је и лексема тата и старешина, што је „генерички назив“ за родитеље младенаца (Радан, 2006: 69), у Радимни је забележено тата, али и отаи (Томић, Радимци: 454), а у Свиници тата, тајка.

2.8.2.2. Женски родитељ је мајка, мајћа, мама, матер, матера, матерја, мати, маћа, нана. У Карашеву и Свиници је регистровано мама, у Радимни такође, али и мати (Томић, 1987: 454; Томић, 1989: 73) и нана (Томић, 1989: 81). Занимљиво је да Томић бележи и рођена мајка (Томић, 1989: 131).

2.8.3. У Карашеву је де̣те 'син', а де̨фка 'кћер', а у Свиници је забележено девка, деука, дешка (Томић, 1984: 136).

2.8.4. На свадби је обавезно присуство брата и то је 'крвни сродник, изводио је младу и предавао је деверу од кога је за узврат примао симболичну суму новца' (Петровић-Савић, 2009: 98). Томић у Радимни бележи рођени брат и рођена сестра (1989: 131). У Карашеву поред номинационих јединица брат и сестра, забележени су и бајца 'старији брат' и цејка 'старија сестра' ${ }^{35}$, у Радимни бата 'старији брат' (Томић, 1989: 11), а у Свиници лојка 'старија сестра' (Томић, 1984: 166). На простору Србије забележено је баја / бајка / бајћа 'старији брат”'”6 и дада / дода / датка / дадка са значењем 'старија сестра'.

У Карашеву су регистровани и термини први варул (брат од стрица, тетке или ујака), прва веришора (сестра од стрица, тетке или ујака) $)^{37}$, други варул (брат као даљи рођак), друга веришора (сестра као даља рођака) ${ }^{38}$. Миле Томић у Свиници бележи веришора са значењем 'сестра од тетке, стрица, ујака' (Томић, 1984: 127).

2.8.5. Учесници свадбе су и баба, деда, као 'очева или мајчина мајка', тј. 'очев или мајчин отац'.

У Карашеву су то: де̨да 'дед’ и мајка 'баба', али јављају се и чукунде̨да и чукунмајка 'прабаба', као и унук и унука. У Свиници је регистровано деда, али и деда дедин у значењу 'прадеда' (Томић, 1984: 136.

По тврђењу Владимировне, лексеме чукундерда и чукунмајка се у Карашеву не односе на четврто колено, како је обично код Срба (Бјелетић, 1994: 200).

2.8.6.1. Посебну улогу имао је ујак и то је 'мајчин брат; њему је у свадбеном ритуалу поверавана улога старог свата и био је обавезно

оца: нена, -е м. '1. отац; 2. таст/свекар' (<*nan-)“ (Радан, 2006: 69).

${ }^{35}$ Владимировна сматра да је ова лексема бугарски дијалектизам (2019: 148).

36 'Старији брат, девер' (Богдановић, 2016: 28).

37 У руском 'двоюродый брат', тј. 'двоюродная сестра' (Владимировна, 2019: 131).

38 У руском 'троюродый брат', тј. 'троюродная сестра' (Владимировна, 2019: 131). 
присутан' (Петровић-Савић, 2009: 151). У неким крајевима номинује се и као yjкa, yjћa. У Карашеву је регистровано ујка. У Свиници постоји лексема тајка чије значење је, поред 'отац', 'тата', и 'ујак' уколико је он старији од оца (Томић, 1984: 223).

2.8.6.2. Без посебног задужења у свадбеној церемонији био је 'очев брат' номинован као стрии, чича, у Карашеву стрича, код Радимаца чича, тј. као вар. ћuћa, а у Свиници ч'uч'a и вар. ћ'uћ'a (Томић, 1984: 238).

2.8.7. Улогу особе која је задужена за магијске радње „како би младожења слушао младу“ (Петровић-Савић, 2009: 124), могла је имати и младина тетка 'сестра једног од младиних родитеља'. И у Карашеву је тетка и 'мајчина и очева сестра', а код Радимаца је забележено: тета, тетка, теткица, али и нина у значењу 'стрина, тета' (Томић, 1989: 86).

2.8.8. Учесници свадбе су и остали рођаци: стрина, ујна, теча (тетьк, тетин) и други. Код Владимировне они су сврстани у групу оних који су дошли путем брачног сродства, будући да она врши поделу на крвно и брачно сродство (Владимировна, 2019: 132), што јесте чињеница, али ја их сврставам овде зато што су се они у тренутку када се свадба дешава нашли у статусу рођака младе или младожење.

2.9. Им енов ањ е особапрема новонастали о одн с и м а. Ступањем у брачну заједницу, успостављали су се посебни односи између двеју породица, па је следила и неминовна номинација особа као последица новонасталих односа.

2.9.1. Родбина једне стране према другој номинована је као пријатељи, пријетељи, приетељи.

2.9.1.1. Тако је 'младожењин или младин отац родитељима оног другог', тј. 'снахин или зетовљев отац, али и свако од њихова рода' номинован као пријатељ, пријетељ, прика. И у Карашеву је регистровано пријетељ, приетел, а у Радимни пријатељ.

2.9.1.2. Аналогно томе, 'снахина или зетовљева мајка, али и свако од њихова рода' (Богдановић 2016: 166), тј. 'младина или младожењина мајка родитељима оног другог’ (Петровић-Савић, 2009: 139) номинују се лексемом пријатељииа, пријетељица, приетељииа, прија, пријана, а код Срба у Румунији претелица (Радан, 2006: 69; Владимировна, 2019: 132) и пријатељииа, пријатељка, као и прика (Томић 1989: 119).

2.9.2. 'Мужевљева мајка' је свекрва, свекрова, а 'мужевљев отац' је свекар. Тако је и код Срба у Румунији (Томић, 1987: 454). У РМС је у значењу 'мужевљева мајка' зебележен и облик свекра, означен као покр. 
2.9.3. 'Женин отац' је таст, деда, али и стараи ${ }^{39}$, а младина мајка је младожењи ташта или баба. Код Срба у Румунији забележено је: таст и mашта (Владимировна, 2019: 133), тас („отац девојкин му је тас“- Томић, 1987: 454), maшта ${ }^{40}$ (Томић, 1987: 454), тј. тьс, тьшт и ташта, тьшта, у Свиници (Томић, 1984: 223, 224), а Радан доноси следеће информације: „Младин отац је младожењи таст, -ове м. /К, J/, тест, -ове /P/, mьcm, -ове /оКГ/, а мати јој је ташта, -е ж /К, J/, тешта, -е /P/“ (Радан, 2016: 69).

У значењу 'ташта' јавља се и младина мама (Владимировна, 2019: 114).

У Свиници се у речнику налазе лексеме кускра 'мајка снаје или зета' и кускру 'отац снаје или зета' (Томић, 1984: 163), а такве облике Владимировна бележи у Јабалчу (2019: 132), што је сведочанство о процесу неразликовања таста од свекрве и таште од свекрва, што је, по Владимировној, источноромански модел (2019: 133).

2.9.4. Синовљева жена је сна ${ }^{41}$, снава, снаја, снајка, снајица. У Карашеву је снаја (Владимировна, 2019:133), у Радимни је забележено снаша (Томић, 1989: 141), а у Свиници сна, снаа, снаја (Томић, 1984: 218).

2.9.5. Младожења је младиним родитељима (и њеној фамилији) зет (Томић, 1989: 46; Томић, 1984: 141; Владимировна, 2019:133).

2.9.6.1. Младожењин брат је девер, ручни девер, ђевер ${ }^{42}$, а његова жена је деверииа ${ }^{43}$, али и јетрва, јетрова. Лексема девер редовно је бележена и у српским говорима у Румунији (Томић, 1989: 32; Томић, 1984: 136; Владимировна, 2019: 127). У Карашеву је регистрована лексема јетрва, али и иеека (Владимировна, 2019: 133).

2.9.6.2. Женин брат је шурак, а његова жена шурњава / шурњаја / шурнајћа ${ }^{44}$. Владимировна бележи шурњак и бајцо (2019:133). У Свиници је регистрована лексема шура (Томић, 1984: 243), у Радимни шура(к) и шурин, као и шурњаја и шурњакиња Томић, 1989: 173).

2.9.7. Женина сестра је бьлгъза $a^{45}$, свастика, сваја. Ову лексему нисам пронашла код Срба у Румунији у поменутим радовима.

\footnotetext{
${ }^{39}$ Овако је у Рађевини (Петровић-Савић, 2009: 147).

${ }^{40}$ У текстовима: „Пољубјо је таста и ташту“ (Томић, 1987: 454).

41 'Снаха, синовљева или братовљева жена' (Богдановић, 2016: 187).

${ }^{42}$ Он је имао посебну улогу да од младиног брата прихвати младу, куповао јој је обућу и вео, прве брачне ноћи спавао између младенаца и водио коња на којем ће млада од своје куће доћи младожењиној (Петровић-Савић, 2009: 106).

43 'Мајка или жена деверова' (Богдановић, 2016: 65).

44 'Жена жениног брата', 'шуракова жена' (Богдановић, 2016: 231, 232).

45 У лику балдуза ова лексема се налази као одредница у Етимолошком речнику српског језика, св. 2, а потиче од турског baldiz (2006: 126).
} 
Владимировна примећује да се лексеме шурак, јетрва, заова и свастика осећају архаичнима и уместо њих се употребљавају вокативне форме бајио и цејко „если адресат старше говорящего, в ином случае обращаются по имени“" (2019: 133).

2.9.8. Онај коме је неко кум у односу на кума је кумашин ${ }^{46}$ или прикумак ${ }^{47}$, а таква женска особа је кумача ${ }^{48}$ или кумашинка. Радан доноси податак о лексеми фељин са овим значењем као позајмљеницу из дакороманског (2006: 71).

2.9.9. Овде припадају и друге особе које немају увек неку посебну улогу, као што је заова, зьлва.

2.10. М у з и ч а р и. Музичари се помињу у наративима о свадби, али мало је номинационих јединица за те особе. Без музике није било свадбе, те су стога и они учесници у свадбеном обичају.

2.10.1. Општи назив за онога ко се бави овим послом јесте: свирач, свириија, чалгииија. Владимировна из Карашева доноси свирац и музикант ${ }^{49}$. О томе код Радана налазимо: „Неопходни и незамењиви учесници у свадбеном обичају јесу свирачи. Све до осамдесетих година прошлога века то су били Цигане м. 'Цигани' (јд. Циганин), а главни инструменат на којем су свирали била је лав међуратном периоду јавља се и кордијон, -и (ређе акордијон) 'акордеон', а касније и други инструменти). Због тога су се пре код Карашевака свирачи звали лав виолиниста'." (Радан, 2006: 71).

У Радимни се јавља свираи и свирач, музикант и музиканач (Томић, 1989: 135, 77), док у Свиници имамо музикалаи и вар. музиканаи (Томић, 1984: 174).

Општи назив за припадника групе музичара је бандащиј ${ }^{51}$, тј. бандис,

\footnotetext{
${ }^{46}$ РМС ову лексему дефинише као хип. од кум.

47 У РМС прикумак је 'кумов помоћник при венчању или крштењу'.

${ }^{48}$ По РМС кумача (покр.) је 'девојка која се посестрими с другом девојком', а овакво значење забележено је и у Радимни (Томић, 1989: 65). О овом обичају говори Биљана Сикимић у раду Теренска истраживањ а Срба у Клисури: обичај кумачење, штампаном у Исходиштима бр. 4, за 2018. годину (стр. 309-322).

${ }_{49}^{49}$ Радан такође тврди: „Данас се користи термин музикант, -и м. и свиращ“ (Радан, 2006:71). За лексему музикант Владимировна каже да је позајмљена из румунског (2019: 135).

50 „Лексему ла́фта и изведеницу лав ${ }^{\phi}$ та́ш, налазимо скоро у свим словенским и несловенским балканским језицима, па и у источним и западним словенским језицима, а бројне индиције иду у прилог томе да је она позајмљеница из немачког језика Laute [Skok, II: 275]“ (Радан, 2006: 71).

51 'Припадник сеоске свирачке банде (групе)' (Богдановић, 2016: 29).
} 
у Радимни је забележена лексема банда у значењу 'група свирача'52 (Томић, 1989: 10), а у Свиници лексема банда значи 'оркестар' (Томић, 1984: 119), а фанфара 'дувачки оркестар’ (Томић, 1984: 232)53, а према информацији М. Радана и код Карашевака се јавља ова лексема са идентичним значењем.

2.10.2. Честа је номинација свирача на одређеном инструменту.

Забележене су следеће лексичке јединице: 'свирач на басу' (инструмент туба) басаиија, 'свирач на гајдама' гајдар / гајдариија / гајдащија / гајдаш / гадљар, гајдаруша, 'онај који свира у дудук' дудуклија / дудучар, 'свирач на кавалу' кавалиија, 'онај који свира у кларинет' кланеција / кланеташ, 'свирач на леуту' левутар, лавутарка, 'виолинист' је ћеманаш / ћеманиија, ‘бубњар у блех оркестру' је гочобија.

Томић из Радимне доноси армуникаш (Томић, 1987: 453) и тобошар ‘добошар' (Томић, 1989: 148), а из Свинице кларинеташ и тобиија. Код Владимировне налазимо: акордеон, виолин, кларинет и бронка (контрабас), али не и назив за свирача на тим инструментима $(2019: 146,147)^{54}$.

2.11. К у л и н а р и. Доста је лексема којима се номинују кулинари, тј. особе задужене за припрему и послужење хране: госпоча, готваљ $a^{55}$, месиља, главна редара, аччибаша, аччија, аччика, ачика, аччијћа, готвар, готварка, готвач, редара, служач, подрумција итд. У Радимни је забележено кувар и куварица (Томић, 1989: 65), у Свиници се бележи куар, вар. куәр, кувар, куварища, кувәрица (Томић, 1984: 162), мада нема назнаке да је то особа која припрема храну и за свадбу. У Карашеву се у оквиру свадбене церемоније помињу такве особе: „Веселила се ужа породица и сви они који су помагали у припремама за свадбу (кувари)“ (Ускату 2017: 513).

У Карашеву, по бележењу Владимировне, јавља се и настојник ${ }^{56}$ (2019: 135). Исту лексему бележи и Радан уз тврдњу да је улога настојника веома важна ,у припремању и нормалном одвијању свадбе“. То су обично ,људи и жене, обично који су ближи род младенаца, но могу то бити и пријатељи или комшије, задужени за спремање неопходне хране за свадбу (или капару), кувар“ (2006: 70). Он тврди да је почетком XX века са тим

\footnotetext{
52 Према информацији колеге Михаја Радана (на чему сам му захвална) ова лексема са идентичним значењем постоји и код Карашевака.

${ }^{53}$ У Свиници је регистровано и мозика поред музика (Томић, 1984: 173).

${ }^{54}$ Драгоцене податке у вези са музиком доноси Селена Ч. Ракочевић у раду Игранке у српским селима Дунавске клисуре у Румунији, штампаном у Исходиштима бр. 4, из 2018. године (стр. 293-308).

${ }_{55}$ Термини готварийа, месарийа и сл. регистровани су и у говорима других словенских језика (Алексова, 2013: 262; Легурска и др., 2012: 49, 66).

${ }^{56}$ Ову лексему Владимировна сврстава у тзв. локална образовања, односно „карашовенизме“ (2019: 148).
} 
значењем употребљавана лексема кок ${ }^{57}$, а да је то „данас архаизам изашао из употребе“. У употреби је, по њему, „У новије време, под утицајем српског језика“, и лексема кувар, али нешто ређе (Радан, 2006: 70).

Алексова бележи овакву терминолошку јединицу приписујући јој значење 'мъж, който поучава младоженеца през първата брачна нощ' (2013: 260). Такву улогу, по Алексовој, могу имати и настојници 'млади съпрузи, съветници на младоженци в първата брачна нощ' (2013: 260).

Подаци о именовању особа задужених за припрему и послужење хране обично изостају у деловима у којима се говори о храни у оквиру свадбене церемоније код Срба у Румунији, упркос чињеници да је део о припреми и послужењу хране веома богато заступљена у наративима.

3.1. При доношењу било каквих закључака мора се имати у виду да се до података о учесницима у свадбеним обичајима долази тако што се покушава извршити реконструкција онога што је било, а то значи да се подаци прикупљају на основу сећања. Не може се са сигурношћу тврдити да нечег нема само зато што у одређеном тренутку сакупљач тих информација није дошао до таквог податка ${ }^{58}$. Такође је очигледна генерацијска и временска дистанца између сакупљача и информатора. Да је сакупљач добро знао шта треба да тражи и очекује, можда би то помогло информатору да се сети свих (или већине) детаља.

3.2. Готово на сваком простору, у мањој или већој мери, може се кроз овакву грађу препознати сусрет култура, при чему „контакти различитих етничких група неизоставно проузрокују и интерференцију на језичком плану“ (Радовановић, 2015: 375). За номинацију учесника у свадбеним обичајима код Срба у Румунији може се узети као закључак тврдња М. Р. Ускату: „Структура карашевске свадбе јесте, без сумње, у највећој мери српска, али има и доста елемената који су преузети из румунских свадбених обреда“" (2017: 515). Наравно, овоме треба додати и чињеницу да у свадбеној терминологији Срба и у Србији и у Румунији има доста позајмљеница из језика и народа са којима су кроз историју долазили у контакт (латинизми, турцизми, германизми и др. $)^{59}$.

Поклапања између разматраних јединица су бројна и она сведоче о истоветности култура истог народа који стицајем историјских околности

\footnotetext{
${ }^{57}$ По њему, „кок јесте позајмљеница из немачког језика“ (Радан, 2006: 70).

${ }^{58}$ Та констатација важи и за овај осврт. Он је резултат извора које сам ја за ову прилику консултовала, али чињеница је да сам током израде овога рада често долазила до нових сазнања. У једном тренутку сам морала престати са потрагама за новим речима овога типа како бих рад привела крају. То сигурно значи да сам испустила бројне лексема које припадају овој скупини, а њихово одсуство је сметња валидности закључака.

${ }^{59}$ О овоме вид. и Радан, 2006: 72.
} 
живи на различитим крајевима и у двема државама. Разлике су резултат и последица различитог окружења.

3.3. Највећи део свадбене терминологије код Срба у Србији и Срба у Румунији који је идентичан словенског је порекла: младожењ невеста, снаја, кум, кума, кумица, сват, старисват ${ }^{60}$ (стари сват), девер ${ }^{61}$, деверериц̧а, мама, пријатељ (пријетељ), гости итд.

3.4. Терминологија сродства показала је да неки облици сведоче о очувању прасловенске терминологије (брат, мама, мати, сестра, свекрва, свекар, таст, ташта).

3.5. Поједини ликови представљају специфичне творбене моделе. Неки су настали додавањем различитих суфикса на исту основу: свадбаш, просник, према: свадбар, свадбарош, просаџ, просиочи и сл.

3.6. Диференцијалне лексеме могу бити најмање двојаке. Једне су резулатат међујезичке интерференције, а друге су аутохтоне.

У прве спадају мошули, забележени у Карашеву као својство говора који је претрпео румунски утицај. Сама лексема је сведочанство о туђем утицају, будући да се ради о маскираној особи као учеснику свадбе, о чему нема података на другом просторима. Овде спадају и неки термини сродства: први варул, прва веришора, други варул, друга веришора, кускра, кускру и др., преузети из румунског.

Бројни ликови из терминологије сродства, који нису позајмљенице, такође су диференцијални: бајцุа (старији брат), изејка (старија сестра), нена $(\text { отац })^{62}$, говија (млада), деверље (браћа невесте или други њени рођаци мушког пола), чукунмајка (прабаба), стрича (стриц) итд.

Лексема ләжљь својим фонетизмом сведочи да долази са простора на коме се чува полугласник. Међутим, чињеница да се сличан термин јавља и у западној Бугарској сведочи о нешто ширем ареалу и о томе да се изодоксе и изопрагме (линије разграничења елемената духовне и материјалне културе) простиру и преко државних, етничких и других граница. Томе у прилог иде и лексема говија. У вези са овом лексемом налазимо податке и код Б. Сикимић (2006: 59) ${ }^{63}$.

${ }^{60}$ „Сват јесте свеслов. и праслов. термин из агнатске породице, који су позајмили и Албанци — starisvat [Skok, III: 369] и Румуни — tărisfat [Maluckov: 215]“ (Радан, 2016: 67).

${ }^{61}$ Истражујући етимологију ове лексеме Радан долази до закључка да је реч „ие., балтосл., свеслов. - из праслов. деิверъ [Skok, I: 415], у КГ има следећа значења: 1. девер, пратилац младе током свадбе; 2. мужевљев брат“ (Радан, 2016: 68).

${ }^{62}$ М. Радан ову лексичку јединицу сврстава у лексичке реликте 2006: 72).

${ }_{63}$ У напомени бр. 19 она доноси следеће податке: „Пантелић [1975: 134] за ‘невесту’ код 
3.7. Неки турцизми карактеришу поједине крајеве: Ђувегија, чалгищија, а други су шире (муштулгција) или широко распрострањених (чауш).

3.8. Називи учесника свадбених обичаја пружају бројне податке о обичајима у вези са спајањем двоје младих у брачну заједницу - упознавању, припреми свадбе, току свадбе, догађајима непосредно након свадбе - говоре о томе шта је исто, а шта различито код Срба у разним крајевима или у култури разних народа.

\section{Литература}

Алексова, 2013:В. Алексова, Сватбената терминология в българския ирумънския език. София: Универзитетско издателство „Св. Климент Охридски“.

Бјелетић, 1994: М. Бјелетић, Терминологија крвног сродства у српскохрватском језику, Јужнословенки филолог, бр. 50, 199-207.

Богдановић, 2016: Н. Богдановић, Антропографски речник југоисточне Србије. Српски дијалектолошки зборник, бр. 63. Београд: Институт за српски језик CAHУ, 1-276.

Владимировна, 2019: Д. К. Владимировна, Лексика свадебной обрядности в славянском и рмынском идиомах карашевцев в исторической области Банат. https://iling.spb.ru/dissovet/theses/koner/thesis.pdf преузето 1. 10. 2019. године

Владимировна, 2019: Д. К. Владимировна, Двуязычная лексика карашевской свадьбы: акциональный код, у: Живот посвећен трагағу за етничким идентитетом, Зборник у част универзитетском професору др Михају Радану поводом 65. рођендана, Темишвар: Западни универзитет у Темишвару, Филолошки, историјски и теолошки факултет, Колектив за српски и хрватски језик и књижевност, 2019, 343-356.

Етимолошки 2006: Етимолошки речник српског језика, св. 2 (БА-БД). Београд: САНУ : Институт за српски језик САНУ.

Златановић, 2014: М. Златановић, Речник говора јужне Србије, Врање: Учитељски факултет.

Златковић, 2014: Д. Златковић, Речник пиротског говора. Београд: Службени гласник.

Зобеница, 2016: С. Зобеница, Из лексике источне Лике. Српски дијалектолошки зборник, бр. 63, Београд: Институт за српски језик САНУ.

Јовановић 2004: В. Јовановић, Речник села Каменице (код Ниша), у: Српски дијалектолошки зборник, бр. LI. Београд: Институт за српски језик САНУ.

Влаха у околини Бора бележи два термина: мирјаса и говија (у селима Горњане и Оштрељ). У Горњој Ресави „Младу зову "гуови", а њену спрему "цуваљи гуови"“ [Бошковић-Матић 1962: 160]. Код Румуна у Банату за 'невесту' потврђена су два термина: govia у Гребенцу и Николинцима [Maluckov 1972-73: 266, 267] и у Ечкој: cinera [Maluckov 1972-73: 271]. 
Лаловић, 2012: Р. Р. Лаловић, Свадбени обичаји у селима око Калиновика. Никшић: Слово, март 2012. Бр. 36-37, 213-232.

Легурска и др., 2012: П. Легурска, Н. Павлова, М. Китанова, Човешкият живот, раждане, сватба, погребение, Тематичен речник на българската семейна обредност. София: Българска академия на науките, Институт за български език „Проф. Любомир Андрейчин“, Печатница на Академично издателство „Проф. Марин Дринов“.

Макаријоска, 2015: Л. Макаријоска, Обредно-обичајната лексика на македонскиот јазик (во споредба со српскиот и бугарскиот јазик), у: Studia macedonica II. Editor Ivan Dorovský, Vydání první Brno: Masarykova univerzita, 132-141.

Макаријоска, 2016: Л. Макаријоска, Македонската и српската свадбена терминологија, у: Аформачија, продлабочување и проширување на вековните културни врски меѓ Р. Македонија и Р. Србија, (Зборник на трудови од Меѓународен научен симпозиум), Битола, 365-373.

Митровић, 1984: Б. Митровић, Речник лесковачког говора. Лесковац: Народни музеј у Лесковцу.

Михајловић 2017: В. Р. Михајловић, Свадбени обичаји и песме села Граничане у околини Лепосавића. Баштина, св. 42, Приштина-Лепосавић: Институт за српску културу, 311-327.

Николић, 2011: Б. Николић, Гостуша. Пирот: Народна библиотека.

Петровић, 2002: С. Петровић, Прежици матријархатског културног модела у ритуалима прелаза, посебно приликом рођења и свадбе, у: Обичајижсивотног ичиклуса у градској средини, Посебна издања 48, Београд: Етнографски институт САНУ, стр. 25-38.

Петровић-Савић, 2009: М. Петровић-Савић, Лексика свадбених обичаја у Рађевини, Монографије 7, Београд: Институт за српски језик САНУ.

Радан, 2006: М. Радан, Из свадбене лексике Карашевака, Исследования по славянской диалектологии. 12: Ареальные аспекты изучения славянскойлексики, Москва: Российская академия наук, Институт славяноведения, 64-75.

Радовановић, 2015: Д. Радовановић, Свадбена лексика у Банату. Исходишта 1, Темишвар-Ниш: Савез Срба у Румунији, Центар за научна истраживања и културу Срба у Румунији, Филозофски факултет Универзитета у Нишу, 375-381.

PMC: Речник српскохрватскога књижевног језика. Књ. 1-3, Нови Сад - Загреб: Матица српска - Матица хрватска, 1967-1969, Књ. 3-6, Нови Сад: Матица српска, 1971-1976.

РСАНУ: Речник српскохрватског књижевног и народног језика. Књ. 1-20. Београд: САНУ и Институт за српски језик САНУ, 1959-2018.

РCЈ: Речник српскога језика. Нови Сад: Матица српска, 2011.

Сикимић, 2006: Б. Сикимић, Свадбена терминологија код Бањаша (румунских Цигана) у селу Трешњевица код Јагодине. Иследования по славянской диалектологии 12, Ареальние аспекты изучения славянской лексики, Москва, Институт славяноведения РАН, 45-63. 
Стојановић, 2010: Р. Стојановић, Црнотравски речник, у: Српски дијалектолошки зборник, бр. LVII. Београд: Институт за српски језик САНУ.

Толстој 1995: N. I. Tolstoj, Jezik slovenske кulture. Niš: Prosveta.

Томић, 1984: М. Томић, Говор Свиничана, у: Српски дијалектолошки зборник, бр. ХХХ. Београд: Институт за српски језик САНУ.

Томић, 1987: М. Томић, Говор Радимаца, у: Српски дијалектолошки зборник, бр. XXXIII. Београд: Институт за српски језик САНУ.

Томић, 1989: М. Томић, Речник говора Радимаца, у: Српски дијалектолошки зборник, бр. XXV. Београд: Институт за српски језик САНУ.

Ћирић, 1983: Љ. Ћирић, Говор Лужнице, у: Српски дијалектолошки зборник бр. XIX. Београд: Српска академија наука и уметности и Институт за српски језик САНУ.

Ћупићи, 1997: Д, Ћупић, Ж. Ћупић, Речник говора Заграча, у: Српски дијалектолошки зборник, бр. XLIV. Београд: Институт за српски језик СAHУ.

Ускату, 2017: М. Р. Ускату, Карашевска свадба данас - обичаји, ритуали и њихова значења. Исходишта бр. 3, Темишвар-Ниш: Савез Срба у Румунији, Центар за научна истраживања и културу Срба у Румунији, Филозофски факултет Универзитета у Нишу.

Цветковић, 2004: М. Цветковић, Хроника села Гаре - Заплање. Ниш: МБ Графика.

Шкаљић, 1966: A. Škaljić, Turcizmi u srpskohrvatskom jeziku. Sarajevo: Izdavačko preduzeće „Svjetlost“.

Йордана С. Маркович

\section{НОМИНАЦИЯ УЧАСТНИКОВ В СВАДЕБНЫХ ОБЫЧАЯХ У СЕРБОВ В СЕРБИИ И РУМЫНИИ}

Резюме

Старые обычаи теряются или меняются. Те, кто соблюдают и остаются, включают свадбеные обычаи. Они всегда были немного или совсем разные в разных частях. В последенее время было много иностранного влияния в этой области, которое проходит через иностранные фильмы. Поэтому любая запись этих обычаев и лексикы очень значительна. В этом документе представлен перечень словаря именования участников в свадебных обычаях, т.е. словарь из области антропологических единиц, назначающих человека, который имеет какую-то функцию в этих обычаях в Сербии и в Румынии, с целью показать, что эти имена является общим в свадебных обычаях, а что результат языкового и культурного вмешательства. Материал был взят из литературых по данной теме.

Ключевые слова: обычай, свадьба, словарный, лексика, участник. 